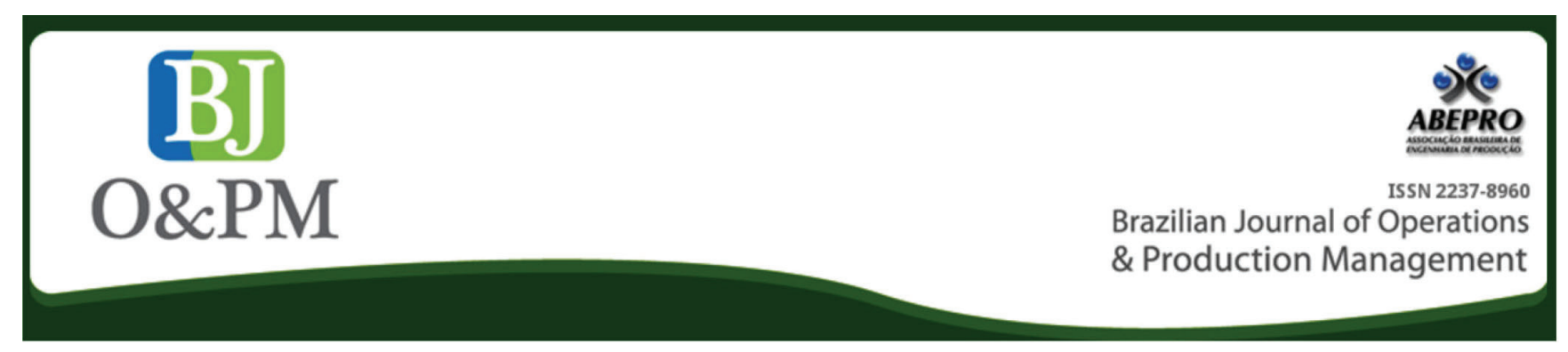

\title{
SUSTAINABLE PRACTICES AND THE RELATIONSHIP WITH SUPPLIERS IN SSCM: A CASE STUDY IN WHOLESALE
}

\author{
Arthur Antonio Silva Rosa \\ arthurasr@hotmail.com \\ Federal University of Uberlândia \\ - UFU, Uberlândia, Minas Gerais, \\ Brazil.
}

\section{Etienne Cardoso Abdala} etienneabdala@hotmail.com Federal University of Uberlândia - UFU, Uberlândia, Minas Gerais, Brazil.

\section{Luciana Oranges Cezarino} Icezarino@gmail.com Federal University of Uberlândia - UFU, Uberlândia, Minas Gerais, Brazil.

\begin{abstract}
Goal: The present study aimed to analyze how sustainability of suppliers affect the sustainability of a wholesaler-distributor located in the city of Uberlândia, Minas Gerais, Brazil.

Design / Methodology / Approach: A qualitative approach was chosen using the case study and content analysis as methodologies and the main instrument for data collection was the interview.

Results: The results suggest a direct relationship between the sustainability of the focal company and that of supply chain members, so that the alignment of Triple Botton Line (TBL) practices along the chain is essential to emphasize the effects of these practices and for the company to be considered sustainable, as indicated by sustainable supply chain concepts.

Limitations of the investigation: The main limitation was the use of a single case study, which does not allow the generalization of results to other companies.

Practical implications: It was possible to analyze the relationship between the sustainable practices of suppliers and the focal company to confirm the need to align sustainable practices throughout the supply chain. The results suggest that companies could improve their performance in environmental, social and economic terms if they observe and evaluate the sustainability of their suppliers, reducing environmental risks and future losses.

Originality / Value: In terms of literature, this is a topic that has not been explored yet in terms of the applicability of sustainability in the supply chain, especially in practical issues in the wholesale sector.
\end{abstract}

Keywords: Sustainable Supply Chain; Sustainable Practices; Suppliers; Wholesale. 


\section{INTRODUCTION}

The theme of sustainability has gained a lot of notoriety over the last decades and was the subject of several debates and agreements in the international scenario that aims to establish commitments in favor of the planet, since it is known that the incessant search for the development compromises the environment and places our future at risk. Thus, to follow this trend and to meet the pressures of the government, entities and even the customers themselves, the business world has been adopting measures that aim to reduce the negative impact on the environment through sustainable development.

Organizations begin to develop techniques to reorganize their production processes so that they increase quality, generate less waste, emit less pollutants, and reuse materials, for example. This new model of production was known as Cleaner Production, which began to be developed in 1980. With the improvements in the studies on the subject, companies begin to adopt corporate sustainability, not only worrying about the results financial and environmental actions, but also with social issues, indicating a change in the corporate world (Barbieri, 2004).

Given that organizations perceive the importance of the relationship with their chain, and the constant pressures of the stakeholders for their adherence to the three dimensions of sustainability (environmental, social and economic), the Sustainable Supply Chain Management concept (SSCM) (Seuring and Müller, 2008) consists of the integrated and cooperative management among all the members of a supply chain so that all the steps and processes involved in the manufacture of the product are always aimed at reducing the impacts on the environment and society as a whole.

Few studies have looked at the SSCM's view of the three areas of the Triple Botton Line (TBL) (Pagell and Wu, 2009; Seuring and Müller, 2008), and the most recent studies that deal with this topic involve the manufacturing, food and automotive industries (Ansari and Kant, 2017). According to Ansari and Kant (2017), the logistics sector occupies the fifth place as a selected branch in the main studies of chain sustainability, that is, the sector still lacks studies in the SSCM area.

Considering this fact, the importance of the management that applies the concepts of sustainability in the supply chain as a strategy for the permanence of a company in the market, and the issue that, according to Pagell and Wu (2009), for a company to be considered sustainable, all its suppliers must also be sustainable, this research aims to describe and analyze the sustainable practices of a focal company and its relationship with the supply chain, in order to identify whether the sustainable practices of the suppliers affect the sustainability of that company. Then it is asked if this situation can be replied in the context of wholesaler, pushing the analysis forward from previous studies (Stock and Seliger, 2016). The work focus in the focal company sustainable initiatives (Evangelista et al., 2017; Abbasi and Nilsson, 2016), enhancing the analysis to supply chain, considering company practices among supply chains.

In addition to this introduction, the present study has the following sections, respectively: literature review, methodology, presentation of results, discussion and, finally, the research conclusions.

\section{LITERATURE REVIEW}

Environmental problems have always been present in the history of mankind, especially since the advent of industrialization, which gradually increased environmental risks with new technological and productive instruments (Vaz, 2010). The classical school considered only three fundamental factors for economic growth. They are the land (natural resources), the capital, and the work with almost no concern with the environment, and only from 1970 did a greater amount of studies on the environmental problems begin to emerge (Mikhailova, 2004).

According to Oliveira et al. (2012), these studies aimed to harmonize the relationship of development as a whole with nature and society itself, since the degradation of natural resources increased due to the continuous increase in production. In this sense, the term "sustainability" was officially presented in 1987 in the World Commission on Environment and Development (CMMAD), which produced the report Our Common Future, defining sustainable development as "capacity to meet the needs of the present, without compromising the ability of future generations to meet their own needs, "further demonstrating that economic growth and sustainable practices are not necessary.

The term management of sustainable supply chains designed to conceptualize sustainable management activities in a supply chain comes years after the construction of a more detailed theoretical reference on supply chain management and is highlighted by the articles published by Kleindorfer et al. (2005), Jayaraman et al. (2007), and Seuring and Muller (2008). The study by Seuring and Müller (2008) particularly suggests that suppliers are an important part of building a sustainable supply chain as they are one of the elements responsible for the induction of sustainable actions in the focal company.

According to Almeida (2002), as the concept of sustainability expands in the business environment, organizations begin to notice sustainable production not only as a way of 
preserving the environment, but also as an opportunity for competitive advantage. According to the author, for a company to be sustainable, it must constantly seek measures that lead to eco-efficiency, in all areas, noting that with these measures companies can "produce more and better with less: more products of better quality, with less pollution and less use of natural resources".

Gonçalves-Dias et al. (2009) suggest that the main concepts of SSCM are based on the relationship that has been consolidated between studies and publications on environmental management and those related to supply chain management. Although the interest in SSCM is not a new academic environment, evidence indicates that the field has reached a critical point in concluding that an increase in the adoption of sustainable supply management practices can become more potent (Jayaraman et al., 2007; Cruz, 2008; Pagell et al., 2010).

The efficient management of natural resources, coupled with loss reduction, can significantly reduce costs in a company, and it also differentiates from competitors (Porter and Van Der Linde, 1995). In this sense, Coral (2002) proposes some practices (sustainability model) that can be adopted by companies that wish to join TBL (Figure 1). According to the author, one factor that has a great contribution for the organizations to reach sustainable goals is the modification of their productive processes in order to generate the least negative impact on the environment.
The term supply chain involves the entire network of autonomous or semi-autonomous organizations that are responsible for acquiring resources, adding value and releasing a given product or service (Pires, 2004). In this way, Sustainable Supply Chain (SCM) refers to the management of the integration of all the activities (flow of goods, information and resources) of a chain, prioritizing interorganizational relations and cooperation between members in order to achieve a common goal (Ching, 2007).

Supply chain management seeks to reduce costs and organizational waste, increase quality and flexibility, as well as be directly related to the level of service offered to customers. Through well-managed management, it is possible to increase new customer profits and increase competitiveness (Ballou, 2001). Christopher (2007) complements that cooperation and good relationship with members of the chain (aided by information technology) provides a superior and lasting competitive advantage over its competitors.

In this sense, supply chain management incorporates the concept of corporate sustainability, meeting the demands of stakeholders, and then SSCM emerges. Seuring and Müller (2008) defines SSCM as the management of the flow of information, material, capital and also cooperation among members of the supply chain, with the objective of performing well in all three dimensions of the Triple Bottom Line. The authors also point out that all members of the chain must follow established sustainability criteria so

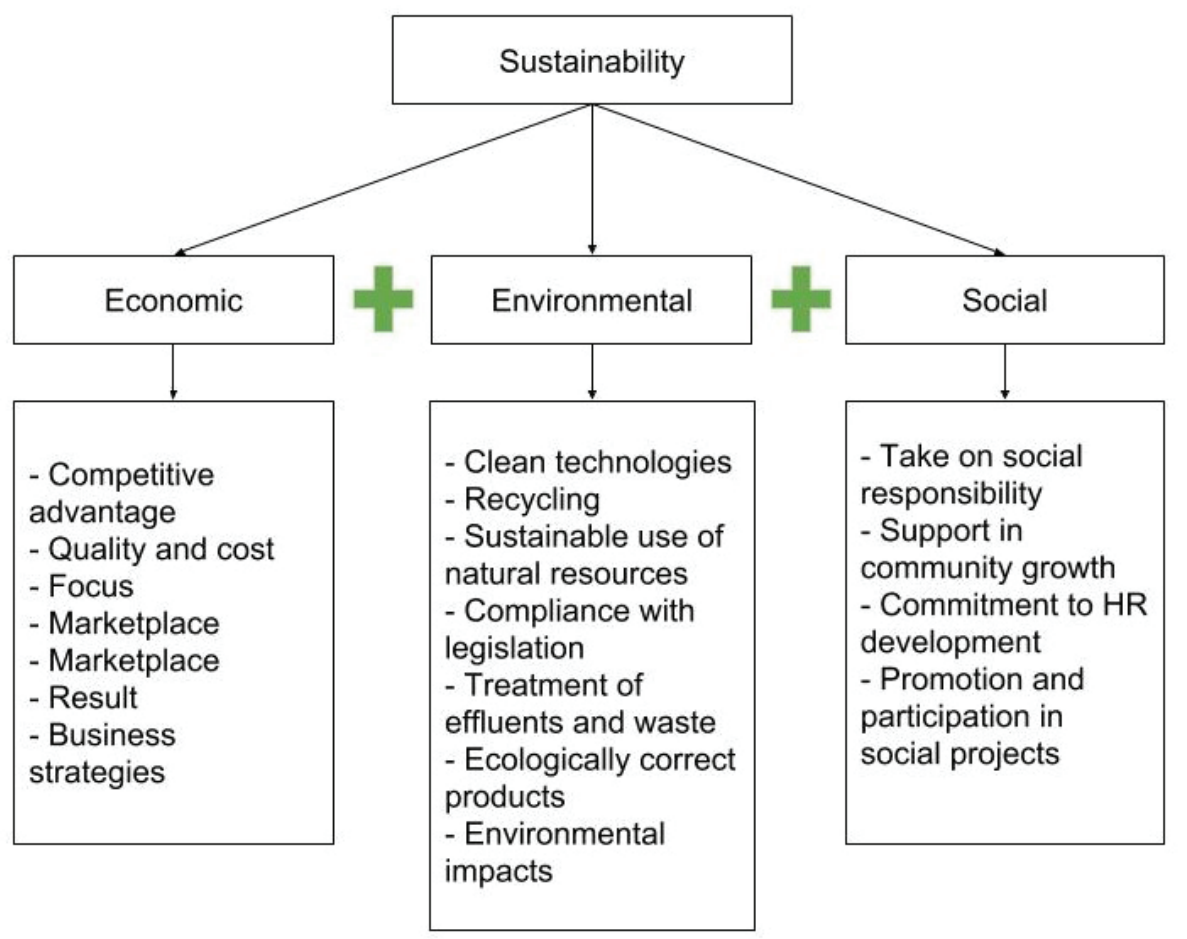

Figure 1. Business sustainability model Source: Adapted from Coral, 2002, p. 136. 
that they can remain in the chain. By this point, SSCM offers a competitive advantage over traditional supply chain management.

In the environmental dimension, Vachon and Klassen (2006) suggest environmental monitoring practices and environmental collaboration to improve chain performance. The first one seeks to monitor and evaluate the actions of the suppliers, verifying that they are in agreement with the commitments made in relation to environmental issues and also with the regulations. The second consists of a strong relationship between the focal company and its suppliers in order to propose joint actions to solve identified environmental problems along the supply chain, in addition to defining goals together. Among the goals exemplified by the author are the reduction of emissions of polluting gases in the atmosphere, recycling, disposal of planned packaging, training of employees, and reduction of environmental impacts in general.

Regarding the social dimension of TBL, it is recommended that the focal company understand the negative impacts caused by the company itself and seek to engage with the surrounding communities, develop social projects, offer better working conditions, and assume its social responsibility (Pullman et al., 2009; Coral, 2002). Finally, in the economic context, Dias (2006) states that companies should keep their business economically viable and profitable.

More recent papers and research on this subject present the motivations for deploying SSCM as well as highlighting sustainable practices, focus on collaboration between supply chain links and the view that environmental issues can be strategic spin-off for the company (Ahi and Searcy, 2013; Beske et al., 2014; Pagell and Shevchenko, 2014; Silvestre, 2016; Evangelista et al., 2017; Holman et al., 2018).

Brandenburg and Rebs (2015) developed a research in which most of the studies on SSCM involve sustainable supply chain modeling, indicating that the most cited elements are sustainable chain goals, trade-offs between costs and emissions of pollutants, and the three dimensions of TBL (economic, social and environmental). Most studies involving the TBL dimensions suggest that win-win relationships are actually complicated to be implemented. The conceptual view is that sustainability should be considered a strategic element but it is difficult to observe its application in an strategic bias in practice.

These findings are in accordance with the results found in the studies of Pagell and Shevchenko (2014) and Evangelista et al., (2017). Evangelista et al. (2017) assert that while there are many studies highlighting the importance of sustainability as a strategic issue for logistics servers, there is a great deal of uncertainty as how environmental efforts translate into results in practice. Pagell and Shevchenko (2014) believe that although sustainability has become an extremely relevant issue for the supply chain management, what is known about the subject is not enough to create a sustainable chain. Studies carried out in companies that are not really considered sustainable are still the norm in scientific studies.

\section{METHOD}

A qualitative study was conducted for collecting data from the biggest wholesaler-distributor of Latin America. Data was analyzed and the content analysis method was used to establish some categories resulting from the process of data interpretation, such as: internal sustainable practices, social practices, legislation influence, impact on company image, suppliers's evaluation, and suppliers sustainability. Uberlândia, Minas Gerais, is a wholesale hub in Brazil, where large companies are located in the logistics sector, representing $21 \%$ of the product gross of the city (Uberlandia Municipality Database, 2019).

A large wholesale company located in the city of Uberlândia was selected for data collection. The choice of the sector and the city is justified because it is a major wholesale hub in Brazil, where large industries are located in the logistics sector, whose activity has a significant impact on the economy of the state and the country. Wholesale companies play a central role in the supply chain, mediating between a large number of members who are in supply chain (factories / industries) and downstream (retailers) directions, allowing the proposed case study to reach the objective of the research, portraying the reality of the whole, even in a dynamic context (Eisenhardt, 1989).

The sources used to carry out the data collection were: physical documents made available by the company; institutional website of the wholesaler and its Social Institute; and semi-structured interviews with four leaders from areas relevant to the development of the research (Yin, 2010). There were 3 interviews with a total of 4 interviewees, who are:

- $\quad$ Purchasing director: The interview lasted 57 minutes and information was collected on the relationship of the wholesaler with its suppliers and with customers, internal processes and the economic scope of TBL.

- Logistics leader and risk and environment management leader: The two leaders were interviewed together, lasting 1 hour and 16 minutes. The collected information aimed at the logistics operations carried out by the company, scope of action, composition 
of the fleet, and the sustainability inserted in these processes.

- Coordinator of the Social Institute: The interview lasted 48 minutes, and information was collected on the sustainable practices carried out by the Social Institute (external practices) and by the organization itself (internal practices).

The interviews were conducted between December 2017 and February 2018, at the company's administrative headquarters and were recorded for later transcription. The identity of the company and the interviewees was kept confidential by prior decision (Guerra, 2010). The triangulation of data from various sources of evidence, relating them to theory, increases the reliability of research, especially when it comes to a single case study, which is the case in this article (Eisenhardt, 1989; Yin, 2010).

Several sources of evidence were used by the research allowing several evaluations to be made on the same phenomenon, leading to the validity of the construct (Yin, 2010).

Research instrument was elaborated from theoretical section of this article, considering the studies of Coral (2002), Vachon and Klassen (2006), Pullman et al. (2009), Pagell and Wu (2009), and Paulraj (2011). From this, the interview script was formulated, relating questions to socio-environmental practices, relationship with the supply chain and the impact of sustainability on the actions carried out by the company and its main suppliers.

Data analysis was performed by content analysis, allowing inferences to be made. From this, the categories of analysis present in the Table 1 below emerged. And in the last phase, the results obtained were compared with those found in the theories (Bardin, 2011; Yin, 2010).

Concerning the use of the case study, figure 2 below presents the protocol used phase by phase, demonstrating the importance of the theory for the construction of the data collection instrument and the subsequent analysis and comparison with the theoretical concepts.
Table 1. Analysis categories

\begin{tabular}{|c|c|}
\hline Categories & Description \\
\hline processes & $\begin{array}{c}\text { Wholesaler operational activities where } \\
\text { sustainable attitudes are applied }\end{array}$ \\
\hline Internal actions & $\begin{array}{c}\text { Actions internal to the company that aim } \\
\text { to promote sustainability }\end{array}$ \\
\hline $\begin{array}{c}\text { Actions taken } \\
\text { by the W }\end{array}$ & $\begin{array}{c}\text { Activities carried out by the Social Institute } \\
\text { aimed at communities at the regional and } \\
\text { national levels }\end{array}$ \\
\hline $\begin{array}{c}\text { Influence of } \\
\text { legislation }\end{array}$ & $\begin{array}{c}\text { Influence that the legislation exerts so } \\
\text { that the wholesaler adopts sustainable } \\
\text { practices }\end{array}$ \\
\hline $\begin{array}{c}\text { Impact on company } \\
\text { image }\end{array}$ & $\begin{array}{l}\text { Impact that sustainability can cause on the } \\
\text { company image }\end{array}$ \\
\hline $\begin{array}{c}\text { Suppliers practices } \\
\text { Practices performed by suppliers who con- } \\
\text { tribute to an Sustainable Supply Chain }\end{array}$ \\
\hline $\begin{array}{c}\text { Suppliers evaluation } \\
\text { Vendor evaluation process carried out by } \\
\text { the company }\end{array}$ \\
\hline $\begin{array}{c}\text { Actions in conjunc- } \\
\text { tion with the supply } \\
\text { chain }\end{array}$ & $\begin{array}{c}\text { Practices that are carried out in coopera- } \\
\text { tion between the members of the supply } \\
\text { chain that lead to sustainability }\end{array}$ \\
\hline \multicolumn{2}{|c|}{ Source: Elaborate by authors }
\end{tabular}

\section{THE MAIN RESULTS}

The company $\mathrm{Y}$ is a large wholesale-distributor located in the city of Uberlândia, and is considered one of the largest wholesalers in Latin America. The company makes deliveries all over Brazil, through its own fleet or through the 33 outsourced carriers. The wholesaler started its activities more than 60 years ago and currently has more than 14 thousand items in its portfolio that are divided into 280 categories. The company has 4,000 employees hired directly, approximately 600 suppliers, and 400 thousand customers, with a turnover of R\$ 5 billion in 2016.

The results found in research demonstrate some categories that are describe in table 2 . Each category was created by content analysis of the information collected in the interviews with Logistics and Risk Management Officer.

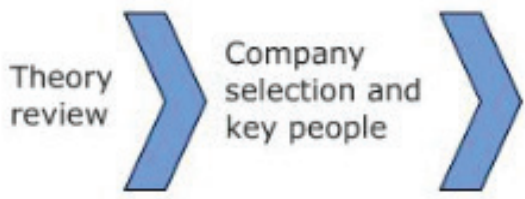

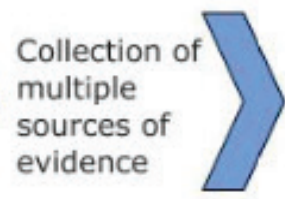

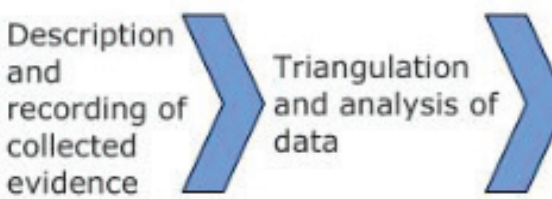

Compare the results obtained with the theory

Figure 2. Single case study protocol 
Table 2. Sustainable Practices in Wholesale

\begin{tabular}{|c|c|c|}
\hline Category & Main results & Authors \\
\hline $\begin{array}{l}\text { Operational } \\
\text { processes }\end{array}$ & $\begin{array}{l}\text { Use of reusable boxes; } \\
\text { Cardboard boxes are reintroduced in the operational processes when they are not damaged; } \\
\text { Reverse logistics of cardboard boxes, lamps and other materials, in partnership with its customers; } \\
\text { Recycling of tailings from the operation, such as paper and damaged cartons and paper; }\end{array}$ & $\begin{array}{l}\text { Beamon (1999); } \\
\text { Vachon and Klassen } \\
\qquad(2006)\end{array}$ \\
\hline Internal actions & $\begin{array}{l}\text { Use of LED lamps throughout the company; } \\
\text { Monitoring of electricity consumption and actions aimed at reducing it; } \\
\text { Preference for digital documents, reduction of the amount of printing and use of recycled papers; } \\
\text { Periodic maintenance of the fleet and monitoring of the emission of polluting gases; } \\
\text { All vehicles use the Arla 32, which reduces the emission of pollutants into the atmosphere; } \\
\text { Donation of products whose due date is close. Donations are made throughout the country; } \\
\text { People management area carries out actions that promote the well-being of employees, } \\
\text { through recreations, commemorations of special dates, availability of gym and guaranteeing } \\
\text { occupational safety; } \\
\text { Creation of University Z, which promotes education for small and medium-sized retailers. } \\
\text { Certifications such as Great Place to Work (GPTW); hiring companies to audit the statements; } \\
\text { A-rating by Fitch Ratings; }\end{array}$ & $\begin{array}{l}\text { Beamon (1999); } \\
\text { Vachon and Klassen } \\
\text { (2006); Dias (2006) }\end{array}$ \\
\hline $\begin{array}{l}\text { Actions taken } \\
\text { by the W }\end{array}$ & $\begin{array}{c}\text { The social institute of the company carries out socio-environmental projects, aiming the devel- } \\
\text { opment of entrepreneurship in young people through the course eZAPe! covering almost all } \\
\text { national states; } \\
\text { Promotes the engagement and development of socio-environmental practices in its partners } \\
\text { through the VemSer program, aiming at supporting the community and preserving nature; } \\
\text { Environmental actions of reforestation through projects such as the Amazonas Sustainable } \\
\text { Foundation (FAS). }\end{array}$ & $\begin{array}{l}\text { Pullman et al. } \\
\text { (2009); Coral (2002) }\end{array}$ \\
\hline $\begin{array}{l}\text { Influence of } \\
\text { legislation }\end{array}$ & $\begin{array}{c}\text { Intense pressure from the regulatory bodies, mainly IBAMA (Brazilian Institute of Environment } \\
\text { and Renewable Natural Resources) for the transportation of products that have the potential to } \\
\text { cause harm to the environment, according to the UN number, with the required documentation; } \\
\text { Training of drivers aiming at the appropriate reactions in case of accidents with products } \\
\text { harmful to nature; } \\
\text { Initiative of the company to develop, as an innovation, the cargo box, which prevents product } \\
\text { leakage into the environment during transportation and contamination of other products; } \\
\text { Support to government and regulatory agencies in developing new standards. }\end{array}$ & $\begin{array}{l}\text { Beamon (1999); } \\
\text { Vachon and Klassen } \\
\qquad(2006)\end{array}$ \\
\hline $\begin{array}{l}\text { Impact on com- } \\
\text { pany image }\end{array}$ & $\begin{array}{c}\text { Valorization of the company image; } \\
\text { Direct relationship between sustainability and organizational image; } \\
\text { Creation of the W Institute, which sought to intensify the socio-environmental practices of } \\
\text { the company; } \\
\text { Creation of the risk and environment area; } \\
\text { Requirement of certifications regarding the sustainability of its suppliers and customers. }\end{array}$ & $\begin{array}{l}\text { Pullman et al. } \\
\text { (2009); Coral, } \\
\quad(2002)\end{array}$ \\
\hline $\begin{array}{l}\text { Practices of } \\
\text { suppliers }\end{array}$ & $\begin{array}{c}\text { Development of long-term contracts and relationships; relationship values respect; win-win re- } \\
\text { lationship; certification requirements for sustainability and quality; Top to Top meetings, which } \\
\text { aim to solve problems and propose strategies in partnership. }\end{array}$ & Dias (2006) \\
\hline $\begin{array}{l}\text { Suppliers evalu- } \\
\text { ation }\end{array}$ & \begin{tabular}{|} 
Constant evaluation of suppliers through software. Suppliers and customers also evaluate the \\
wholesaler as a form of feedback. Direct contact with the company president for troubleshoot- \\
ing. Valuation of characteristics, such as flexibility, delivery on time, correct product according \\
to the negotiation, support in times of instability in the market and sustainability of the suppli- \\
er. If the supplier performs unsustainable practices as a form of punishment, negotiations are \\
immediately interrupted.
\end{tabular} & $\begin{array}{l}\text { Beamon (1999); } \\
\text { Seuring and Müller } \\
\text { (2008); Kowalski } \\
\text { (2016) }\end{array}$ \\
\hline $\begin{array}{c}\text { Actions in } \\
\text { conjunction } \\
\text { with the supply } \\
\text { chain }\end{array}$ & $\begin{array}{l}\text { Partnerships for preservation of the environment, correct destination of damaged products, } \\
\text { community actions, reverse logistics, customer support or future projects of the W Institute. }\end{array}$ & $\begin{array}{l}\text { Beamon (1999); } \\
\text { Seuring and Müller } \\
\text { (2008) }\end{array}$ \\
\hline
\end{tabular}




\section{DISCUSSION}

Regarding the social scope of sustainability, company $Y$ always sought to carry out projects for the benefit of the community; however, in 2005, the company founded an own institute that intensified social and environmental actions, reinforcing its commitment to society. The eZAPe! - Entrepreneurial Virtues, which is always expanding, allows young people to develop the vision of entrepreneurship beyond what is traditionally taught, helping them to lead personal and professional life. The $W$ Institute also has a series of partners that allow the institute to operate throughout the country and in the most diverse areas of social and environmental projects. These projects reflect the company's involvement with society, as presented by Pullman et al. (2009).

The coordinator of the Social Institute emphasizes that the main focus of the institute is entrepreneurship, and that this focus is directly linked to the beliefs and values of the founder, the shareholders and the company: "[...] it is no use you have created something that has no similarity or closeness, which does not have with its essence and its culture [...]". It also complements that "in the creation of the institute, the focus on education was very natural, since the company already believed that education is the only way out for the development of Brazil, because University Z was aimed at training the small retailer."

In this sense, the development of the Safe Cargo (considered a market solution), together with Brazilian Association of Technical Standards (Associação Brasileira de Normas Técnicas - ABNT, at the initiative of the company itself and with partnerships with members of the chain, affirms its involvement with the environmental cause and attests that governmental and social pressures contribute to the development of innovations in the processes, as presented by Porter and Van Der Linde (1995). According to the risk and environment manager:

"Products characterized as dangerous according to their UN number are allocated within the Safe Cargo, which has safety locks that, in case of accident or leakage, does not contaminate other products and does not leak into the environment, and can do the job with specialized companies in case of emergency."

Even if the $\mathrm{W}$ Institute does not aim to promote the image of the company $Y$ as of bank $X$ by conducting only B2B negotiations, its actions and company practices imply directly the image of both its maintainers. The institute annually publishes an activity report for the knowledge of the stakeholders, according to Norman and MacDonald (2004). In this sense, the organization recognizes that although the profit is of vital importance for the company, the image is its great- est asset and sustainability is one of the ways to improve it and to remain competitive in the market. The wholesaler requires certifications from its suppliers and customers to have a guarantee that its image will not be impaired (Pagell and Wu, 2009; Lima, 2007; Seuring and Müller, 2008; Almeida, 2002).

Transparency is one of the factors cited by Seuring and Müller (2008) that characterizes a SSCM and is also present in company $Y$ by sharing information with suppliers, such as resale price and consumer complaints. In addition, still based on the characteristics of a SSCM presented by the author, company $\mathrm{Y}$ sets performance goals in relation to TBL with its suppliers, such as investment in environmental preservation.

The distributor wholesaler periodically hires specialized companies to audit their financial statements. These companies are renowned in the market in order to impart greater security and reliability to the stakeholders. In addition, the distributor changes auditing company but keeping the same goals (Norman and MacDonald, 2004).

It is observed that the wholesaler has a series of legal requirements to comply, especially with regard to environmental aspects, such as the transportation of high-risk products, which shows that the government exerts pressure for the adoption of environmentally responsible practices through regulations (Riesktir, 2012). However, it can be seen that the wholesaler carries out environmentally responsible practices, not only due to legal requirements, but also due to the concern with natural resources, which is linked to the company's values.

Cooperation also occurs through supplier support in times of market instability. Two of the factors promoting integration are the very good relationship between the parties and reciprocity in the method of evaluation between company-supplier and company-client. The firm Y seeks to develop long-term contracts with its suppliers, having a partner base, which may be more flexible in terms of delivery or payment negotiations, for example, as pointed out by Seuring and Muller (2008). This is one of the factors that differentiate SCM from SSCM.

This factor demonstrates the strong involvement of the target company of this study with its suppliers, having a strong interaction and exchange of information between them, thus developing confidence among supply chain members. In relation to the selection of suppliers, the possession of certifications is considered a prerequisite for the start of negotiations, a factor that is also present in the SSCM (Seuring and Mülller, 2008).

They are carried out recurrently and aim at adjusting the objectives in common - including in relation to TBL -, cor- 
recting the deviations and elaborating plans for a following period, in order to optimize the results. And Advantage Report $^{\mathrm{TM}}$, software used by company $\mathrm{Y}$, allows a broad assessment of vendors in each item and also avoids the distortion of this information that transits between the company's departments to the supplier, allowing more accurate feedbacks (Cristopher, 2007; Pagell and Wu, 2009).

According to the purchasing director:

"The company $Y$ makes three types of investments in software to evaluate and be evaluated by suppliers. We want to know what the suppliers think of company $Y$; according to the GPTW, they evaluate how the environment is; and third, we also want to know the customers who buy, and what they think of company $Y$."

In this sense, the company $Y$ presents a good relationship with the members of the chain, carrying out partnership actions that contribute to a long lasting relationship (Ching, 2007; Lima, 2007). These actions include the PEG supply contract, which consists of a supplier-company agreement, so that company $Y$ is the correct recipient of defective products received; reverse logistics involving the company $\mathrm{Y}$, customers and suppliers; and the suppliers' support to the social and environmental projects of the company's institute. Management can be observed upstream and downstream of supply chain in relation to TBL as analyzed by Pires (2004).

In the Purchasing Manager's view, the main advantage of the company being part of a sustainable supply chain is that "it is only through an SSC that it will have a long-term organization", indicating that the company is aware that a company that is part of an SSC is more likely to gain competitive advantage and remain in the market.

The results found by Evangelista et al. (2017) were partially different from those found in this research, mainly in relation to the company Y's awareness of the relevance of environmental, social and economic practices (TBL), which is required by law. Even if sustainability is not embedded in the values of company $\mathrm{Y}$, it is present in the company's own culture, while considering that there are still issues to be improved, for example, the wholesaler could use solar energy. In addition to the authors' research, this research also presented the direct relationship between the sustainability of the focal company and that of supply chain members, so that the alignment of TBL practices along the chain is essential to emphasize the effects of these practices and for the company to be considered sustainable.

As the Sureeyatanapas et al. (2018) study, this research has shown that it is possible to simultaneously adopt sus- tainable practices in processes and obtain cost savings, and it has also shown that efforts to improve or adopt new sustainable practices may result in innovations that optimize the operational process, such as the development of the Cargo Box.

For the "degree of importance" given to economic, environmental and social factors, according to the Abbasi and Nilsson (2016) survey, the wholesaler showed a stronger tendency for the economic side, such as making a "good purchase" for a greater margin of contribution and a better price for customers; however, not too distant in order of importance, unlike what the authors' research showed, are the environmental and social factors that have been present throughout the wholesaler's history and confirmed by "punishments" to suppliers that break established sustainable commitments. This demonstrates the concern with the image issue and increasingly seeks to meet the social and environmental demands of stakeholders.

From the results found in the research, highlighting the categories of content analysis performed, it is possible to elaborate a model for the determinants of the sustainable practices of the wholesale company. This Framework can be seen in the following figure 3 :

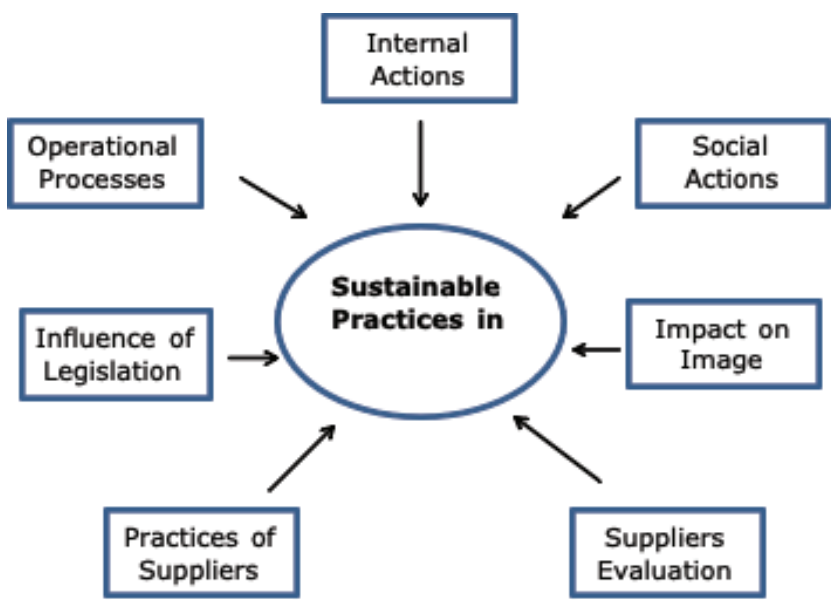

Figure 3. Determinants of Sustainable Practices in Whosale Source: Data research

The analysis categories described in Table 2 are understood in the model of Figure 3 as the determinants of the sustainable practices of wholesale companies. In order to analyze the proof of these categories as determinants, it is suggested to use surveys applied to a significant sample of companies and to perform multivariate statistical analysis, in order to confirm the elements as variables of influence on sustainable practices. 


\section{CONCLUSIONS}

The objective of the research was to show that the sustainability of the suppliers of a company is related to the sustainability of the company. From the information collected by means of the interviews, and using the content analysis method, it was possible to establish some categories resulting from the process of data interpretation, such as: internal sustainable practices, social practices, influence of legislation, impact on company image, suppliers, and evaluation and sustainability of suppliers. Thus, the results were analyzed in comparison with results obtained in other published research on the subject.

The wholesaler-distributor, which was the target company of the study, performs sustainable practices and belongs to an SSCM. Even with pressure from stakeholders to make it a sustainable company, the company performs actions beyond what is required by law.

The results indicate that when suppliers perform unsustainable practices, the operation of the wholesaler and the entire supply chain can be affected or even interrupted. In this sense, the sustainability of the focal company is directly linked to the sustainability of its supply chain suppliers.

In addition, the image of the wholesaler and supply chain members may be compromised by inadequate practices regarding sustainability by some supply chain component. The company has a good relationship with its supply chain, seeking respect and trust in its long-term relationships, conducting mutual evaluations among supply chain members and exchanging information in a strategic way, encompassing aspects of the Triple Bottom Line, both in the relationship and in the company organization itself.

"The association of sustainability as an element that has a positive or negative impact on the company's image is very evident. However, there is no defined action protocol for selecting suppliers for their sustainable practices, and even requiring and worrying about these practices in their supply chain, it is not possible to determine at what level the sustainability of suppliers' actions, or their absence, affects the level of sustainability of the company surveyed" (Rosa et al., 2020).

It should be noted, however, that the wholesaler does not have sustainability as a formal value of the company. In addition, the risk and environment management unit was recently created and there is no clear protocol for supplier selection with respect to criteria to be assessed for sustainability.
The research contributes to the literature because it is a topic still little explored in the Brazilian context and mainly applied in a wholesaler-distributor, with the respective practical implications of the theory. Regarding the limitations, although multiple sources of evidence were used, it was not possible to verify whether the company actually performs all the actions found in the interview. It was also not possible to define at which level the sustainability of the focal company is affected by the suppliers. For future research it is suggested to carry out a multi-case study, covering the focal company and its suppliers.

\section{REFERENCES}

Abbasi, M. and Nilsson, F. (2016), "Developing environmentally sustainable logistics: Exploring themes and challenges from a logistics service providers' perspective", Transportation Research Part D: Transport and Environment, Vol. 46, 273-283.

Ahi, P. and Searcy, C. (2013), "A comparative literature analysis of definitions for green and sustainable supply chain management", Journal of Cleaner Production, Vol. 52, pp. 329-341.

Almeida, F. (2002), O bom negócio da sustentabilidade, Nova Fronteira, Rio de Janeiro.

Ansari, Z. N. and Kant, R. (2017), "A state-of-art literature review reflecting 15 years of focus on sustainable supply chain management", Journal of Cleaner Production, Vol. 142, Part 4, pp. 2524-2543.

Ballou, R. H. (2001), Gerenciamento da cadeia de suprimentos: planejamento, organização e logística empresarial, 4. ed, Bookmann, Porto Alegre.

Barbieri, J. C. (2004), Gestão empresarial Ambiental, Saraiva, São Paulo.

Bardin, L. (2011), Análise de conteúdo, Edições 70, São Paulo.

Beamon, B. M. (1999), "Designing the green supply chain", Logistics Information Management, Vol. 12, No. 4, pp. 332-342.

Beske, P. et al. (2014), "Sustainable supply chain management practices and dynamic capabilities in the food industry: A critical analysis of the literature", International Journal Productions Economics, Vol. 152, pp. 131-143.

Brandenburg, M. and Rebs, T. (2015), "Sustainable supply chain management: a modeling perspective", Annals of Operations Research, Vol. 229, No. 1, pp. 213-252.

Ching, H. Y. (2007), Gestão de estoques na Cadeia de Logística Integrada: supply chain, 3. ed., Atlas, São Paulo. 
Brazilian Journal of Operations \& Production Management

Volume 16, Número 3, 2019, pp. 413-423

DOI: 10.14488/BJOPM.2019.v16.n3.a5
Christopher, M. (2007), Logística e gerenciamento da cadeia de suprimentos: criando redes que agregam valor, 2. ed. São Paulo, Cenlage learning.

Coral, E. (2002), Modelo de planejamento estratégico para a sustentabilidade empresarial, Tese de Doutorado, Universidade Federal de Santa Catarina - UFSC, Florianópolis, SC.

Cruz, J. M. (2008), "Dynamics of supply chain networks with corporate social responsibility through integrated environmental decision-making", European Journal of Operational Research, Vol. 184, No. 3, pp. 1005-1031.

Eisenhardt, K. M. (1989), "Building theories from case study research", Academy of Management Review, Vol. 14, No. 4, pp. 532-550.

Evangelista, P. et al. (2017), "Is environmental sustainability a strategic priority for logistics service providers?", Journal of Environmental Management, Vol. 198, pp. 353362.

Gonçalves-Dias, S. et al. (2009), "Sustentabilidade em Cadeia de Suprimentos: Uma Perspectiva Comparada de Publicações Nacionais e Internacionais", Anais do XXXIII EnANPAD, São Paulo.

Guerra, J. H. L. (2010), "Proposta de um protocolo para o estudo de caso em pesquisas qualitativas", Encontro Nacional de Engenharia de Produção, Vol. 30, pp. 1-13.

Holman, D. et al. (2018), "Sustainable logistics management in the $21^{\text {st }}$ Century requires Wholeness Systems Thinking", Sustainability, Vol. 10, No. 12, p. 4392.

Jayaraman, V. et al. (2007), "Supply chain management in a sustainable environment", Journal of Operations Management, Vol. 25, pp. 1071-1074.

Kleindorfer, P. R. et al. (2005), "Sustainable Operations Management. Production and Operations Management", Vol. 14, No. 4, pp. 482-492.

Kowalski, J. (2016), “A importância do alinhamento Top to Top", available at: https://luckrodotcom.wordpress. com/2016/04/11/a-importancia-do-alinhamento-top-to-top/ (access Feb. 2018).

Lima, A. M. (2007), Instrumentos de reporte de sustentabilidade (Triple Bottom Line), UFSM, Foz do Iguaçu.

Mikhailova, I. (2004), "Sustentabilidade: evolução dos conceitos teóricos e os problemas da mensuração prática", Revista Economia e Desenvolvimento, Vol. 1, No. 16, pp. 22-41.

Norman, W. and MacDonald, C. (2004), "Getting to the bottom of "triple bottom line", Business Ethics Quarterly, Vol. 14, No. 2, pp. 243-262.
Oliveira, L. et al. (2012), "Sustentabilidade: da evolução dos conceitos à implementação como estratégia nas organizações", Production, Vol. 22, No. 1, pp. 70-82.

Pagell, M. and Shevchenko, A. (2014), "Why research in sustainable supply chain management should have no future", Journal of Supply Chain Management, Vol. 50, No. 1, pp. 44-55.

Pagell, M. and Wu, Z. (2009), "Building a more complete theory of sustainable supply chain management using case studies of 10 exemplars", Journal of Supply Chain Management, Vol. 45, No. 2, pp. 37-56.

Pagell, M. et al. (2010), "Thinking differently about purchasing portfolios: an assessment of sustainable sourcing" Journal of Supply Chain Management, Vol. 46, No.1, pp. 57-73.

Paulraj, A. (2011), “Understanding the relationships between internal resources and capabilities, sustainable supply management and organizational sustainability", Journal of Supply Chain Management, Vol. 47, No. 1, pp. 19-37.

Pires, S. R. I. (2004), Gestão da cadeia de suprimentos: conceitos, estratégias, práticas e casos - Supply Chain Management, Atlas, São Paulo.

Porter, M. and Van Der Linde, C. (1995), "Towards a new conception of the environment- competitiveness relationship", Journal of Economics Perspectives, Vol. 9, No. 4, pp. 97-118.

Pullman, M. E. et al. (2009), "Food for thought: social versus environmental sustainability practices and performance outcomes", Journal of Supply Chain Management, Vol. 45, No. 4, pp. 38-54.

Rieksti, A. C. (2012), "ISO 14001 e a sustentabilidade. A eficácia do instrumento no alcance do desenvolvimento sustentável", In Marcovitch, J. (Org.), Certificação e Sustentabilidade Ambiental: Uma Análise Crítica, São Paulo, p. 13.

Rosa, A. A. S. et al. (2020), "Sustainable Practices and the Relationship with Suppliers in SSCM: a case study in Whosale". In: Leiras, A. et al. (Eds.). Operations Management for Social Good. 2018 POMS Conference International in Rio. In press.

Seuring, S. and Müller, M. (2008), "From a literature review to a conceptual framework for sustainable supply chain management", Journal of Cleaner Production, Vol. 16, No. 15, pp. 1699-1710.

Silvestre, B. (2016), "Sustainable supply chain management: current debate and future directions", Gestão \& Produção, Vol. 23, No. 2, pp. 235-249. 
Stock, T. and Seliger, G. (2016), "Opportunities of sustainable manufacturing in industry 4.0.", Procedia Cirp, Vol. 40, pp. 536-541.

Sureeyatanapas, P. et al. (2018), "Green initiatives for logistics service providers: An investigation of antecedent factors and the contributions to corporate goals", Journal of Cleaner Production, Vol. 191, pp. 1-14.

Uberlandia Municipality Database (2019), available at http://www.uberlandia.mg.gov.br/2014/ (access Mar 2019).

Vachon, S. and Klassen, R. D. (2006), "Green project partnership in the supply chain: the case of the package printing industry", Journal of Cleaner production, Vol. 14, No. 6-7, pp. 661-671.

Vaz, D. S. (2010), Alterações climáticas, riscos ambientais e problemas de saúde: breves considerações, in: VI Seminário Latino Americano de Geografia Física; II Seminário Ibero Americano de Geografia Física, pp. 1-11.

Voss, C. et al. (2002), "Case research in operations management", International Journal of Operations \& Production Management, Vol. 22, No. 2, pp. 195-219.

Yin, R. K. (2010), Estudo de Caso: planejamento e métodos, 4 ed., Bookman, Porto Alegre.

Received: 01 Mar 2019

Approved: $22 \mathrm{Jul} 2019$

DOI: 10.14488/BJOPM.2019.v16.n3.a5

How to cite: Rosa, A. A. S.; Abdala, E. C.; Cezarino, L. O. (2019), "Sustainable Practices and the Relationship with Suppliers in SSCM: a case study in Wholesale", Brazilian Journal of Operations \& Production Management, Vol. 16, No. 3, pp. 413-423, available from: https://bjopm.emnuvens.com.br/bjopm/article/view/811 (access year month day). 